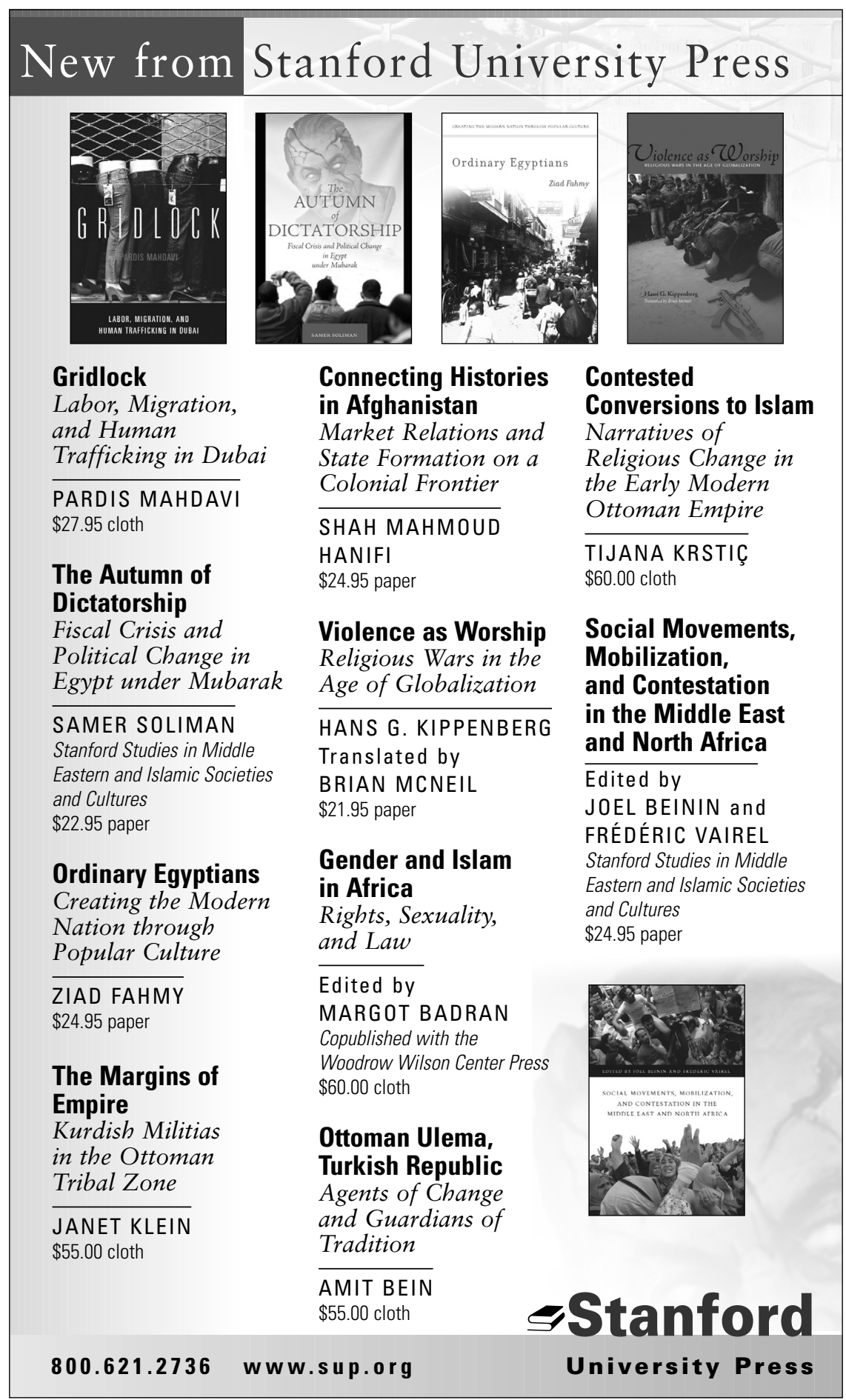




\section{INTERNATIONAL JOURNAL OF MIDDLE EAST STUDIES}

\section{Contributions and Editorial Correspondence}

Send article submissions as e-mail attachments to ijmes@ gc.cuny.edu. Articles must be based on original research and the careful analysis of primary source materials. Manuscripts are evaluated with the understanding that they have not been published elsewhere in any language and are not under consideration for publication elsewhere. Books are not solicited for review from authors or publishers. Those wishing to have books reviewed should send a review copy to the editorial office. Unsolicited book reviews are not accepted. Individuals interested in reviewing books for IJMES should send a curriculum vitae to ijmes@gc.cuny.edu.

\section{Manuscript Preparation and Style}

General. An article must be in English and may not exceed 9,000 words or thirty-five double-spaced pages in 12-point font (including main text, endnotes, tables, and figure captions) with 1-inch margins on all sides. Authors should submit the manuscript as an email attachment using a standard word-processing program. The entire manuscript - including notes, tables, and referencesmust be typed double-spaced and numbered consecutively. IJMES follows a double-blind peer review process, so authors must avoid putting their names in headers or footers and avoid any references to themselves in the body or the endnotes such as might betray their identity to referees. Selected citations of the author's wellknown published work may be included only if the absence of such citations would be conspicuous. Submissions should not include acknowledgments, but these can be added later if the manuscript is accepted. All submissions must include a 150-word abstract and a cover email or letter that includes the author's name, academic discipline and institutional affiliation (if any), land-mail address, telephone number, and e-mail address. The Journal conforms to the Chicago Manual of Style, 15th Edition. Transliteration follows a modified Encyclopedia of Islam system, which is detailed on this page. The editor may return manuscripts that do not conform to the guidelines.

Text. The start of the article and each section should be flush left; other paragraphs should be indented. Do not use desktop publishing features (justified text, bold and underlined fonts, etc.). Block indent long quotations (more than 50 words). Never cross-reference.

Spelling and Punctuation. Use American spelling: color, not colour; analyze, not analyse; traveling, not travelling. Use serial commas: blue, green, and yellow. For quotations, use Americanstyle formatting, which puts the final period or comma inside the quotation marks, for example, "Gandhi said, 'Poverty is the worst form of violence.'” For capitalizations, check the dictionary; when in doubt, do not capitalize. Examples: President Obama; president of the United States; the president

Numbers and Dates. Spell out whole numbers, cardinal and ordinal, from one to one hundred; for exceptions see the Chicago Manual of Style. For percentiles, use numbers but spell out "percent," for example, 20 percent, except in tables and parentheses where it should be $20 \%$. In both text and endnotes, use European, not American, date format, for example, 8 February 2010. Use 20th century, not twentieth century; 1990s, not 1990's or the nineties. Do not use double dating; use common era (A.D.) dates only, unless quoting from an original source, in which case use the date as quoted (e.g., hijra) with the common-era equivalent in brackets.

Notes and References. Notes must be numbered consecutively throughout the text using Arabic numerals, double-spaced, and grouped together as endnotes following the text. Footnotes and intext citations are not permitted, nor are bibliographies. All titles in non-Roman alphabets (Arabic, Cyrillic, etc.) must be transliterated and should follow English-language capitalization rules. Foreign titles in Roman alphabets (French, German, etc.) should follow the capitalization rules of that particular language. English translations of foreign language titles may be provided at the author's discretion. Internet references must include a full URL and an accessed date. Cities of publication should include the country or U.S. state (e.g., Calif., Mass., N.Y.), except for major cities (Boston, Chicago, Los Angeles, New York). The style of note citations should conform to the following examples:

${ }^{1}$ Stanford J. Shaw, History of the Ottoman Empire and Modern Turkey, 2 vols. (New York: Cambridge University Press, 1977).

${ }^{2}$ Jamil M. Abun-Nasr, A History of the Maghrib in the Islamic Period, 3rd ed. (New York: Cambridge University Press, 1987), 10; idem, Muslim Communities of Grace: The Sufi Brotherhoods in Islamic Religious Life (New York: Columbia University Press, 2007), 4

${ }^{3}$ Howard Crane, trans. and ed., Risale-i Mimar' 1 yye: An EarlySeventeenth-Century Ottoman Treatise on Architecture, Studies in Islamic Art and Architecture 1 (Leiden: E. J. Brill, 1987), 71.

${ }^{4}$ Martin Rein and Donald Schon, "Frame-Reflective Policy Discourse," in Social Sciences and Modern States, ed. Peter Wagner, Carol Hirschon Weiss, BjörnWittrock, and Helmut Wollman (New York: Cambridge University Press, 1991), 262-89.

${ }^{5}$ Clifford Geertz, "Toutes Directions: Reading the Signs in an Urban Sprawl," International Journal of Middle East Studies 21 (1989): 291-306.

When references to the same work follow without interruption, use ibid. When notes to the same work follow after interruption, use the author's last name and a shortened title of the book or article. Do not use op. cit:

${ }^{6}$ Shaw, History of the Ottoman Empire, 2:6.

${ }^{7}$ Ibid., 1:10-52.

${ }^{8}$ Social Science Research Council, "Internationalization and Interdisciplinarity: An Evaluation of Title VI Middle East Studies Centers," Social Science Research Council, http://www.ssrc. org/programs/mena/survey_of_middle_east_studies/ (accessed 20 March 2007).

${ }^{9}$ Otis Glazebrook to the U.S. State Department, "Increase in Cost of Living Caused by War," 3 November 1915, consular correspondence, American consulate in Jerusalem, record group 84 , Vol. 72, National Archives at College Park, College Park, Md (NACP).

${ }^{10}$ Muhammad 'Abd al-Rahman al-Maqrami, al-Tajammu' alYamani li-l-Islah: al-Ru'ya wa-l-Masar-Dirasa fi al-Mash'a wal-Tatawwur (Sanaa, Yemen: Yemeni Reform Gathering, 1998).

Foreign Words and Transliteration. If an English term exists for a word, use it. All technical terms from languages written in non-Roman alphabets must be italicized and fully transliterated with diacritical marks (macrons and dots), for example, qasīda. A technical term is defined as a word not found in MerriamWebster's Collegiate Dictionary or a multiword phrase, excluding titles and proper nouns. Diacritical marks, as well as the letters ' ayn and hamza, should be inserted using a Unicode font, preferably Jaghbub Uni. For more information and to download the font, see the Author Resources page of the IJMES editorial office website: http://web.gc.cuny.edu/ijmes. Words that are found in MerriamWebster's should be spelled as they appear there and not treated as technical terms. They should have no diacritics, nor should they be italicized-for example, mufti, jihad, shaykh. See the IJMES Word List on our editorial office website for exceptions that preserve ' ayn and hamza, for example, Qur'an, shari'a, 'ulama'. Diacritics should not be added to personal names, place names, names of political parties and organizations, or titles of books and articles. These words should be spelled in accordance with the IJMES transliteration system but without diacritics. However, 'ayn and hamza should be preserved in all these cases, and should be clearly distinguished from one another, preferably by inserting the symbols ' and ' using the Jaghbub Uni font. Personal and place names with accepted English spellings should be spelled in accordance with English norms, for example, Yasir Arafat, Baalbek, Damascus. This rule 
applies to cities of publication in citations. Names of living individuals may be spelled according to their preferred English spelling. Authors are responsible for the accuracy of their transliterations.

Transliteration System. For Arabic and Persian, IJMES uses a modified Encyclopedia of Islam system, which is detailed in the Transliteration Chart below. Note that ta marbuta is rendered $a$ not $a h$, except in Persian, where it should be $i h$; in Arabic ida fa constructions, it is rendered $a t$. The feminine nisba ending is rendered -iyya (iyyih in Persian). Inseparable prefixes in Arabic are connected with what follows by a hyphen: bi-, wa-, li-, and la-. When one of these prefixes is followed by al, the $a$ will elide, forming a contraction rendered as wa-1-, bi-1-, li-1-, and la-1-. The definite article al- is lowercase everywhere, except when it appears as the first word of a sentence or endnote. When an Arabic name is shortened to just the surname, the al- is retained; for example, Hasan al-Banna becomes al-Banna. Connectors in names-such as bin, ben, abu, and so forth-are lowercase only when preceded by a name, e.g. Osama bin Laden, but Bin Laden, Ibn Khaldun. Follow English capitalization rules for transliterated titles; capitalize all major terms, but not articles, prefixes, coordinating conjunctions, or prepositions. Use italics to indicate a book, newspaper, or periodical. Do not add diacritical marks, but do preserve 'ayn and hamza (except for initial hamza, which is dropped), for example, Faysal al-Tafriqa bayn al-Islam wa-l-Zandaqa and al-Di'aya ila Sabil al-Mu'minin. For Ottoman Turkish, either transliterate according to our chart or use modern Turkish orthography consistently. Persian must be transliterated using the IJMES system, not that of the Encyclopedia Iranica, so $i$ and $u$ must be used, not $e$ and $o$. The Persian izafat is rendered $-i$

Tables, Figures, and Images. Tables, figures, and images must be cited in the text, for example (see Table 1). They should be num- bered consecutively in Arabic numerals, captioned, and appear as a unit at the end of the article. They should not be interspersed in the text. Diagrams must be professionally rendered or computer generated; details should be large enough to remain legible at $50 \%$ reduction. When appropriate, photos may be submitted with a manuscript. Their use will be at the editor's discretion. All images should be submitted in electronic format. For halftones or other illustrations, consult the editor.

\section{Publishing Information}

Production. The publisher reserves the right to copyedit manuscripts to conform to the journal's style, which generally follows the rules found in the Chicago Manual of Style. Spelling will be edited to conform to American usage and Merriam-Webster's Collegiate Dictionary.

The lead author will receive a link to page proofs for the correction of typographical or factual errors only. No rewriting will be allowed in the proof stage. Authors must return the material to the editorial office within 48 hours of receipt or approval will be assumed.

Offprints. The lead author of an article (but not book reviews) will receive a high quality PDF of the article. Offprints may be purchased if ordered at the proof stage. Orders received after the issue is printed are subject to a 50\% reprint surcharge.

Copyright and Originality. Submission of an article implies that it has not been simultaneously submitted or previously published elsewhere. Authors are responsible for obtaining permission to publish any material under copyright. Contributors will be asked to assign their copyright, on certain conditions, to Cambridge University Press. 


\section{IJMES TRANSLITERATION SYSTEM FOR ARABIC, PERSIAN, AND TURKISH}

\section{CONSONANTS}

$\mathrm{A}=$ Arabic, $\mathrm{P}=$ Persian, $\mathrm{OT}=$ Ottoman Turkish, $\mathrm{MT}=$ Modern Turkish

\begin{tabular}{|c|c|c|c|c|c|c|c|c|c|c|c|c|c|c|}
\hline & A & P & OT & MT & & A & $\mathrm{P}$ & OT & MT & & A & $\mathrm{P}$ & OT & MT \\
\hline \& & , & 3 & 2 & - & j & $\mathrm{z}$ & $\mathrm{z}$ & $\mathrm{z}$ & $\mathrm{z}$ & 4 & $\mathrm{k}$ & k or $g$ & $\mathrm{k}$ or $\tilde{\mathrm{n}}$ & $\mathrm{k}$ or $\mathrm{n}$ \\
\hline ب & $\mathrm{b}$ & b & $\mathrm{b}$ & $\mathrm{b}$ or $\mathrm{p}$ & $j$ & - & $\mathrm{zh}$ & $j$ & $\mathrm{j}$ & & & & or $\mathrm{y}$ & ory \\
\hline 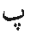 & - & $\mathrm{p}$ & $\mathrm{p}$ & $\mathrm{p}$ & س & $\mathrm{s}$ & $\mathrm{s}$ & $\mathrm{s}$ & $\mathrm{s}$ & & & & or $\breve{g}$ & or $\breve{g}$ \\
\hline ت & $\mathrm{t}$ & $\mathrm{t}$ & $\mathrm{t}$ & $\mathrm{t}$ & ث & sh & sh & $\$$ & $\S$ & ك & - & $g$ & $\mathrm{~g}$ & g \\
\hline 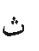 & th & $\underline{\mathbf{s}}$ & $\underline{\mathbf{s}}$ & $s$ & ص & ș & $\stackrel{s}{s}$ & $\underline{s}$ & $\mathrm{~s}$ & $J$ & 1 & 1 & I & 1 \\
\hline$\tau$ & $\mathbf{j}$ & $\mathbf{j}$ & c & c & $\dot{~}$ & d & $\dot{z}$ & $\dot{z}$ & Z & $p$ & $\mathrm{~m}$ & $\mathrm{~m}$ & $\mathrm{~m}$ & $\mathrm{~m}$ \\
\hline ๘ & - & $\mathrm{ch}$ & $c ̧$ & 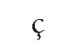 & $b$ & $t$ & $t$ & $t$ & $\mathrm{t}$ & j & $\mathrm{n}$ & $\mathrm{n}$ & $\mathrm{n}$ & $\mathrm{n}$ \\
\hline$\tau$ & $\mathrm{h}$ & $\mathrm{h}$ & $\mathrm{h}$ & $\mathrm{h}$ & ظ & $\mathrm{z}$ & $z$ & z & $\mathrm{Z}$ & . & $\mathrm{h}$ & $\mathrm{h}$ & $h^{1}$ & $\mathrm{~h}^{1}$ \\
\hline$\dot{\tau}$ & kh & kh & $\mathrm{h}$ & h & $\varepsilon$ & c & c & c & - & , & $\mathrm{w}$ & $\mathrm{v}$ or $\mathrm{u}$ & $\mathrm{v}$ & $\mathrm{v}$ \\
\hline د & $\mathrm{d}$ & d & $\mathrm{d}$ & d & $\dot{\varepsilon}$ & gh & gh & $\mathrm{g}$ or $\breve{g}$ & $\mathrm{~g}$ or $\mathrm{g}$ & ي & $\mathrm{y}$ & $y$ & $y$ & $y$ \\
\hline j & $\mathrm{dh}$ & $\underline{\mathrm{Z}}$ & $\underline{Z}$ & z & ف & $\mathrm{f}$ & $\mathrm{f}$ & $\mathrm{f}$ & $\mathrm{f}$ & $\ddot{\partial}$ & $a^{2}$ & & & \\
\hline נ & $\mathrm{r}$ & $\mathrm{r}$ & $\mathrm{r}$ & $r$ & ق & $\mathrm{q}$ & $\mathrm{q}$ & k & $\mathrm{k}$ & ل & 3 & & & \\
\hline
\end{tabular}

1 When $\mathrm{h}$ is not final. 2 In construct state: at. ${ }^{3}$ For the article, al- and $-1-$

\section{VOWELS}

ARABIC AND PERSIAN

Long 1 or is a

$\begin{array}{ll}9 & \overline{\mathrm{u}} \\ \text { s } & \overline{\mathrm{i}}\end{array}$

Doubled $\quad$ iyy (final form $\overline{1}$ )

9- uww (final form $\overline{\mathrm{u}}$ )

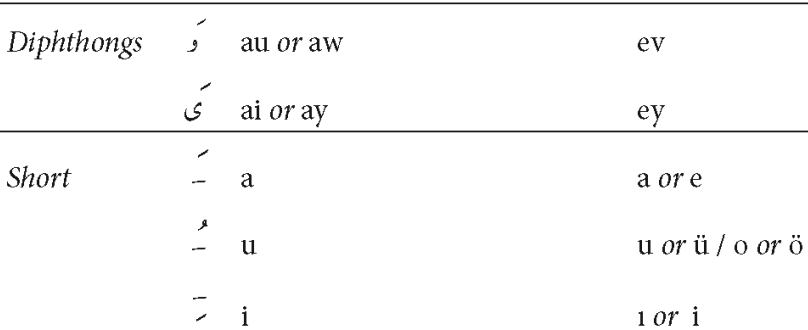

For Ottoman Turkish, authors may either transliterate or use the modern Turkish orthography. 


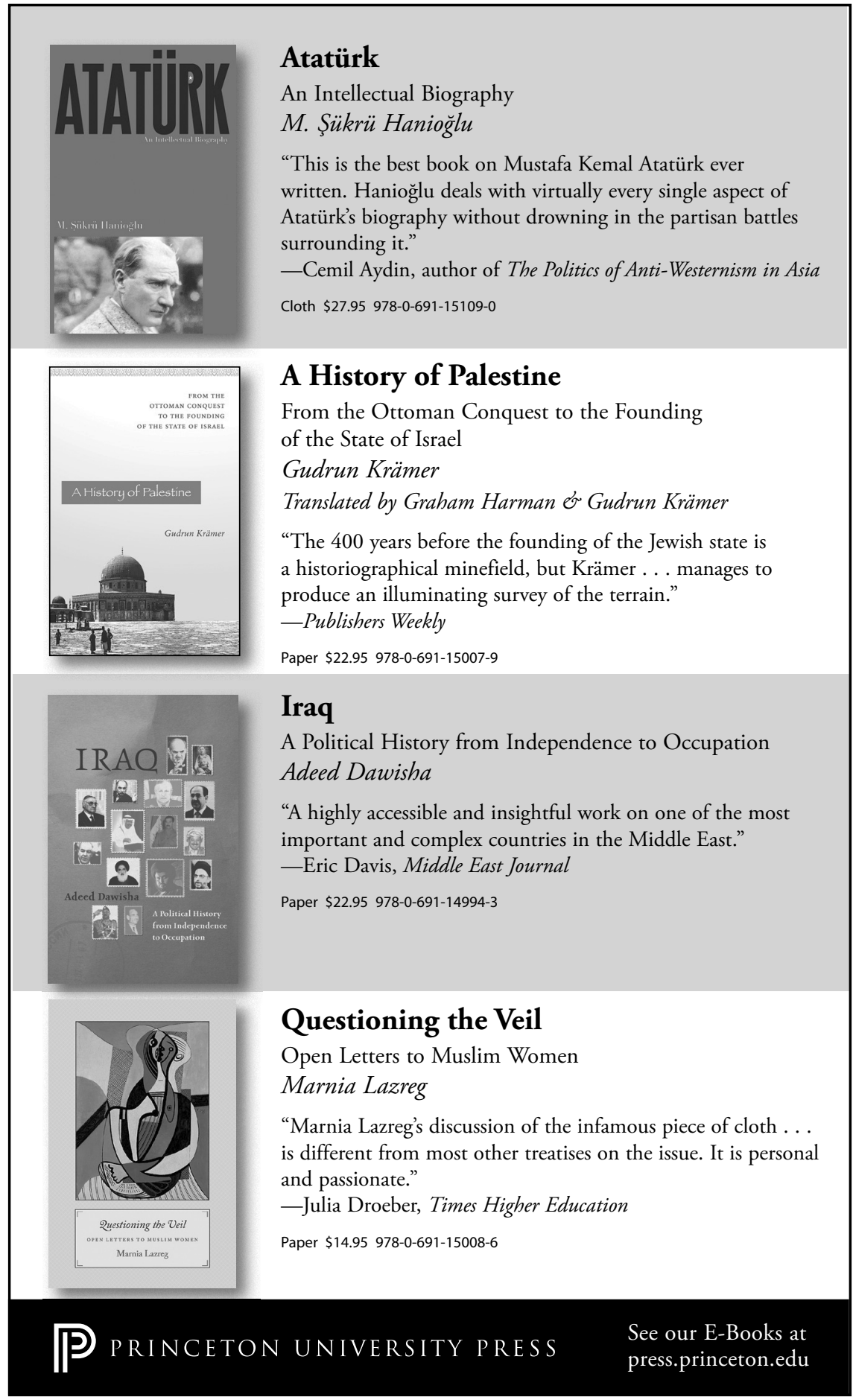




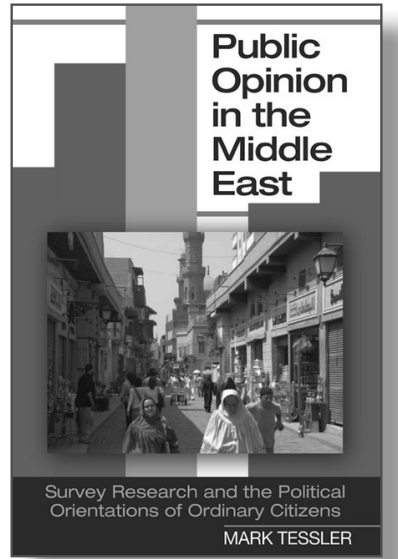

\section{Public Opinion in the Middle East} Survey Research and the Political Orientations of Ordinary Citizens

\section{MARKTESSLER}

Addressing issues of doing survey research in the Middle East, these articles trace the development of key concerns and methodological questions in the study of politics and society in this region. Indiana Series in Middle East Studies paper $\$ 27.95$ cloth $\$ 80.00$

\section{PUBLIC CULTURES OF THE MIDDLE EAST AND NORTH AFRICA}

\section{Memorials and Martyrs in Modern Lebanon}

\section{LUCIA VOLK}

This compelling and lucid study enhances our understanding of culture and politics in the Middle East and the politics of memory in situations of ongoing conflict. paper $\$ 24.95$ cloth $\$ 70.00$

\section{Connected in Cairo}

Growing up Cosmopolitan

in the Modern Middle East

MARK ALLEN PETERSON

This series of thickly described and carefully contextualized case studies describes the social practices that create class identities. paper $\$ 24.95$ cloth $\$ 70.00$

\section{Arab Filmmakers of the Middle East A Dictionary}

\section{ROY ARMES}

A landmark dictionary listing more than 550 feature films by more than 250 filmmakers, this engaging volume covers the film production in Iraq, Jordan, Lebanon, Palestine, Syria, and the Gulf States.

cloth $\$ 39.95$

\section{Shari'a Politics}

Islamic Law and Society in the Modern World

EDITED BY ROBERT W. HEFNER

Studies of eight Muslim-majority societies, and state-of-the-field reflections by leading experts, provide the first comparative investigation of movements for and against implementation of sharia.

paper $\$ 27.95$ cloth $\$ 80.00$

$800-842-6796$ iupress.indiana.edu
INDIANA UNIVERSITY PRESS

INDIANA UNIVERSITY 


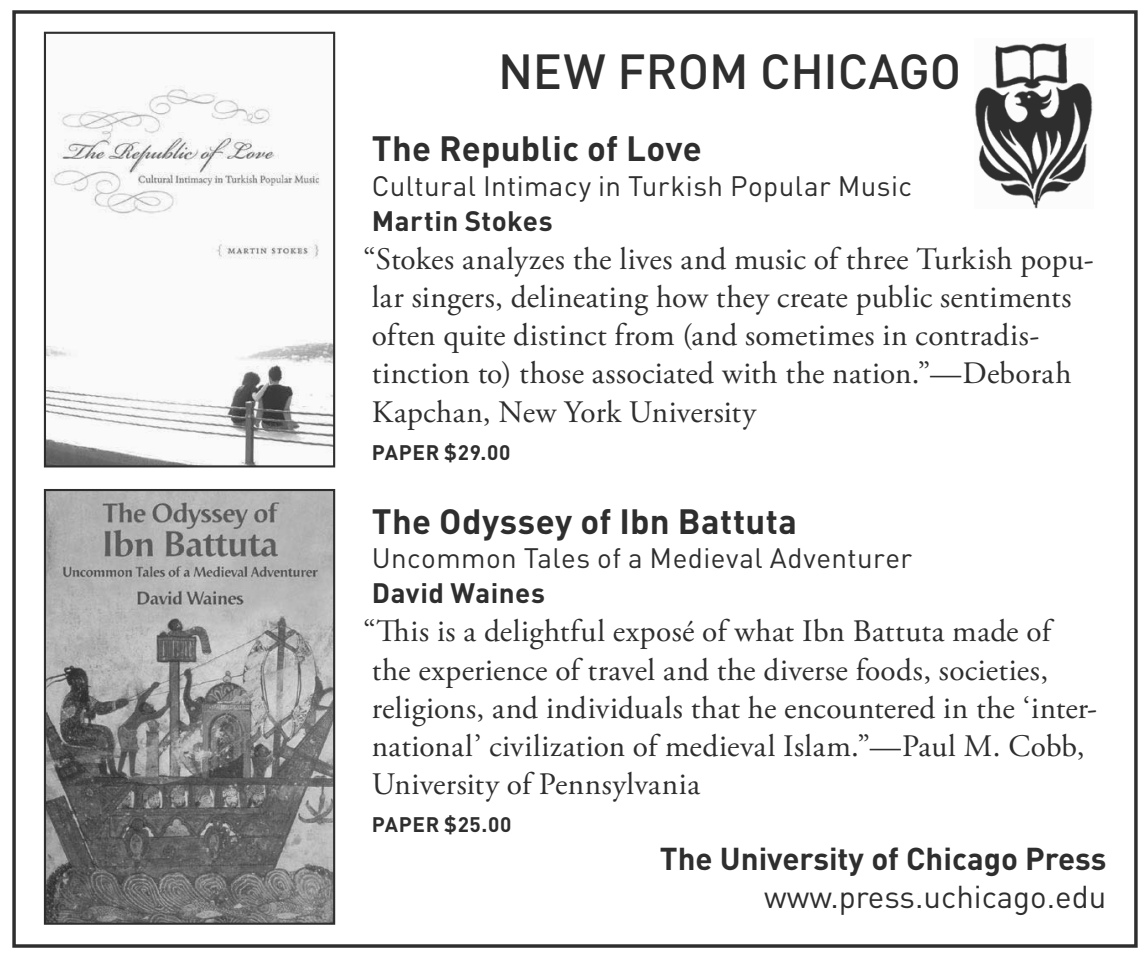


(Contents continued)

Nadera Shalhoub-KeVorkian, Militarization and Violence against Women in Conflict Zones in the Middle East: A Palestinian Case-Study (Suheir Abu Oksa Daoud)

Dawn ChatTy, Displacement and Dispossession in the Modern Middle East (Nell Gabiam)

\section{Empire and Modernity}

Jens Hanssen, Fin de Siècle Beirut: The Making of an Ottoman Provincial Capital (Akram Fouad Khater)

Murat Birdal, The Political Economy of Ottoman Public Debt: Insolvency and European Financial Control in the Late Nineteenth Century (Yücel Terzibaşoğlu)

Osama W. Abi-Mershed, Apostles of Modernity: Saint-Simonians and the Civilizing Mission in Algeria (Nancy E. Gallagher)

SuZAnne Marchand, German Orientalism in the Age of Empire: Religion, Race, and Scholarship (Anna Akasoy)

\section{Politics and Political History}

Anthony Billingsley, Political Succession in the Arab World: Constitutions, Family Loyalties, and Islam (Michael Robbins)

Malika Zeghal, Islamism in Morocco: Religion, Authoritarianism, and Electoral Politics (John P. Entelis)

$349-350$

Lev Luis Grinberg, Politics and Violence in Israel/Palestine: Democracy versus Military Rule (Donna Robinson Divine)

SAÏD AmIR ARJomand, After Khomeini: Iran under His Successors (Babak Rahimi)

Peyman Vahabzadeh, A Guerrilla Odyssey: Modernization, Secularism, Democracy, and the Fadai Period of National Liberation in Iran, 1971-1979 (Maziar Behrooz)

AleXANDER Murinson, Turkey's Entente with Israel and Azerbaijan: State Identity and Security in the Middle East and Caucasus (Umut Uzer)

ÜMit CizRE, ED., Secular and Islamic Politics in Turkey: The Making of the Justice and Development Party (A. Kadir Yildirim)

\section{Arts and Architecture}

Suzanne Pinckney Stetkevych, The Mantle Odes: Arabic Praise Poems to the Prophet Muhammad (Th. Emil Homerin)

Benjamin Brinner, Playing across a Divide: Israeli-Palestinian Musical Encounters (Jonathan H. Shannon)

Nancy Um, The Merchant Houses of Mocha: Trade and Architecture in an Indian Ocean Port (John L. Meloy)

\section{Medieval Studies}

Allen James Fromherz, Ibn Khaldun: Life and Times (Ahmet T. Karamustafa)

ANA ECHEVARríA, Knights on the Frontier: The Moorish Guard of the Kings of Castile (1410-1467) (Stephen Cory)

\section{Anthropology of Islam}

GABRIELE VOM BRUCK, Islam, Memory, and Morality in Yemen: Ruling Families in Transition (Isa Blumi)

\section{NOTES AND COMMENTS}

Noga Efrati, The Effendiyya: Where Have All the Women Gone? 


\section{SPECIAL ISSUE: Relocating Arab Nationalism}

\section{CONTENTS}

\section{EDITORIAL FOREWORD}

Israel Gershoni, Sara Pursley, and Beth Baron

\section{ARTICLES}

\section{Relocating Arab Nationalism}

Peter Wien Preface

Michael Provence Ottoman Modernity, Colonialism, and Insurgency in the Interwar Arab East

JonATHAN Wyrtzen Colonial State-Building and the Negotiation of Arab and Berber Identity in Protectorate Morocco

JAmEs McDougall Dream of Exile, Promise of Home: Language, Education, and Arabism in Algeria

Peter WIEN The Long and Intricate Funeral of Yasin al-Hashimi: Pan-Arabism, Civil Religion, and Popular Nationalism in Damascus, 1937

ORIT BASHKIN Hybrid Nationalisms: Watan̄ and Qawmī Visions in Iraq under 'Abd al-Karim Qasim, 1958-61

\section{ROUNDTABLE}

\section{Relocating the Cold War}

NATHAn J. Citino Between Global and Regional Narratives

Paul Thomas Chamberlin Rethinking the Middle East and North Africa in the Cold War

JefFrey James Byrne The Middle Eastern Cold War: Unique Dynamics in a Questionable Regional Framework

GUY LARON Surveying the Revolutionary Arc

\section{BOOK REVIEWS}

\section{Nations and Their Others}

John ChalcRAft, The Invisible Cage: Syrian Migrant Workers in Lebanon (Samer N. Abboud)

NADER ENTESSAR, Kurdish Politics in the Middle East (Robert Olson)

SAMI SHAlom CheTRIT, Intra-Jewish Conflict in Israel: White Jews, Black Jews (Orit Bashkin)

RACHEL M. ScotT, The Challenge of Political Islam: Non-Muslims and the Egyptian State (Heather J. Sharkey)

Hannibal Travis, Genocide in the Middle East: The Ottoman Empire, Iraq, and Sudan

\section{Cambridge Journals Online}

For further information about this journal please go to the journal website at: journals.cambridge.org/mes

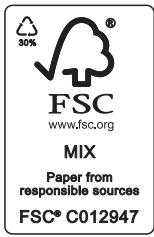

